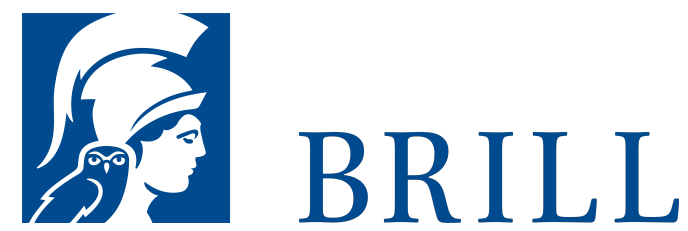

\title{
Exegesis and Poetry in Medieval Karaite and Rabbanite Texts
}

\section{Karaite Texts and Studies Volume 9}

Editors: Joachim Yeshaya and Elisabeth Hollender

This collection of essays offers an inquiry into the complex interaction between exegesis and poetry that characterized medieval and early modern Karaite and Rabbanite treatment of the Bible in the Islamic world, the Byzantine Empire, and Christian Europe. Discussing a variety of topics that are usually associated with either exegesis or poetry in conjunction with the two fields, the authors analyze a wide array of interactions between biblical sources and their interpretive layers, whether in prose exegesis or in multiple forms of poetry and rhymed prose. Of particular relevance are mechanisms for the production and transmission of exegetical traditions, including the participation of Jewish poets in these processes, an issue that serves as a leitmotif throughout this collection.

Readership

Anyone interested in the Hebrew Bible, biblical exegesis, medieval Jewish culture and literature, Hebrew poetry, Jews in the Islamic World, the Byzantine Empire and Christian Europe, and Karaite-Rabbanite relations.

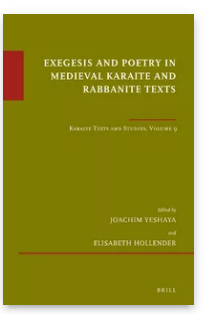

Pages: xvi, 340 pp.

Language: English

Subjects:

Literature \&

Linguistics, Jewish Studies, History \& Culture, Jewish Studies, Byzantine Studies, History Publisher: Brill

Series:

Karaite Texts and Studies,

Volume: 68

Études sur le judaïsme médiéval, Volume: 68

E-Book (PDF)

Released online: 27 Sep 2016

ISBN: 978-9004-33478-6 List price USD \$202.00

Hardback Publication date: o7 Oct 2016 
Joachim Yeshaya, Ph.D. (2009), University of Groningen, is a 04-33511-0 List price postdoctoral fellow at KU Leuven. He is the author of Medieval Hebrew Poetry in Muslim Egypt (Brill, 2011) and Poetry and Memory in Karaite Prayer (Brill, 2014).

Elisabeth Hollender, Ph.D. (1993), University of Cologne, habilitation (2001), Duisburg University, is Professor of Jewish Studies at Goethe University Frankfurt. She has published widely on piyyut and piyyut commentary, including Clavis Commentariorum of Hebrew Liturgical Poetry in Manuscript (Brill, 2005).

For more information see brill.com

Order information: Order online at brill.com +44330 3330049 | customerservices@brill.com Submission information: brill.com/authors

Titles published by Brill | Fink, Brill | mentis or Brill | Schöningh: +49(o)71 5413279216 | brill@brocom.de 